\title{
Multilateralism and MATHIAS Megaregionalism from RISSE the Grounds-of-Justice Standpoint
}

\begin{abstract}
This paper considers the trend towards megaregionalism (TTIP, TPP) that became prominent in the trade domain in the last years of the Obama administration. While megaregionalism has fallen by the wayside since Trump's inauguration, the underlying rationale for such treaties will most likely reassert itself rather soon. So there are structural issues that need to be discussed from a standpoint of global justice. In all likelihood, megaregionalism is detrimental to global justice. TTIP in particular, or anything like it, might derail any possibility for a trade organization to aid the pursuit of justice at the global level, and any possibility that trade will be used to that end. From the standpoint of global justice one must hope that megaregionalism does not replace WTO multilateralism. The global-justice framework used here is the grounds-of-justice approach offered in the author's 2012 On Global Justice.
\end{abstract}

Keywords: Global justice; megaregionalism; trade; WTO; multilateralism; justice

\section{Introduction: Megaregionalism}

The World Trade Organization's (WTO's) multilateralism - its efforts to draw in as many countries as possible given that they would have to satisfy certain membership conditions - has come under siege from many directions. ${ }^{1}$ There are those who, like me, support multilateralism in the trade domain but argue it must come in a different guise and thus hope for a reformed WTO. There are also the economic nationalists who do not believe in international cooperation in the first place, or in any event want to reduce it considerably. There also those who think there should be cooperation but would want to limit it to a smaller number of, say, similarly technologically advanced countries. In his inauguration speech in January 2017, US President Donald Trump encouraged American to 'buy

1 The material in this paper will be integrated into a book on trade justice jointly written with Gabriel Wollner, tentatively called On Trade Justice: A Philosophical Plea for a New Global Deal. For some of the preliminary joint work for that book see Mathias Risse and Gabriel Wollner, 'Three Images of Trade: On the Place of Trade in a Theory of Global Justice', Moral Philosophy and Politics 1/2 (2014), 201-225.; Mathias Risse and Gabriel Wollner, 'Critical Notice of Aaron James, Fairness in Practice: A Social Contract for a Global Economy', Canadian Journal of Philosophy 43/3 (2013), 382-401. As part of our internal division of labor we decided this piece would be under my sole authorship. I am grateful to Gabriel for the ongoing collaboration on these themes and to Marco Meyer for comments specifically on this project. I am also grateful for the discussants at the workshop on TTIP at the European University Institute in Florence (held in June 2016) where I presented this material, and to Miriam Ronzoni for inviting me to that workshop. I am also much indebted to the helpful comments of two anonymous reviewers for this journal, as well as for advice by the editors on finalizing this piece. Note that the conference just mentioned took place several months before the election of Donald Trump as president of the United States. His accession profoundly changed the state of debate on the subject matter of this paper, which subsequently had to be redone to some extent. This is an unusual experience for a philosopher. 
American and hire American.' He announced his administration would choose trade and other policies accordingly. Trump's pronouncements have ushered in a striking reversal to the trade policies pursued by his predecessor. Barack Obama had favored trade agreements with large blocks of countries falling far short of the full range of WTO members. The transition from Obama to Trump changed the US governmental stance from support for megaregionalism to support for economic nationalism.

Partly as a result of the slow-down in the WTO's multilateralism there have been many bilateral and regional agreements. Over the years, the US and the $\mathrm{EU}$, the largest markets, have concluded bilateral agreements (or economic partnership agreements, in the EU context) with a number of mostly Asian and Latin-American countries. However, arguably the most prominent ones among the bilateral and regional treaties that have been under consideration those that have given rise to the term megaregionalism - are the Trans-Pacific Partnership (TPP) and the Transatlantic Trade and Investment Partnership (TTIP). ${ }^{2}$

Involving twelve Pacific Rim countries, TPP was signed in February 2016, after seven years of negotiations. Among other things, TPP contains measures to lower barriers such as tariffs, and establishes an investor-state dispute settlement mechanism. ${ }^{3}$ In January 2017, following Trump's accession to the presidency, the US withdrew from this treaty. As of this writing its future is uncertain.

A substantially more ambitious agreement between US and EU, TTIP as it had been developed in the Obama administration's final stages also featured further-reaching innovations than TPP. In addition to removing direct trade barriers and lowering tariffs yet more, TTIP would likely have included articles on mutual recognition of product standards in areas where they are high in both regions (e.g., cars or pharmaceuticals). Moreover, TTIP sought to create a dialogue about new legislation / regulation in the context of regulatory cooperation. The case for TTIP was both economic and strategic. The economic case was that both US and EU appeared to need a boost after the financial crisis that defined the early years of the Obama administration. The strategic argument was that trade harmonization can establish economic leadership and

2 On TPP, see Gary Hufbauer and Julia Muir, 'The Trans-Pacific Partnership' in Melendez-Ortiz, Bellmann, and Mendoza (eds.), The Future and the WTO: Confronting the Challenges. A Collection of Short Essays (Geneva, Switzerland: International Centre for Trade and Sustainable Development (ICTSD), 2012), 47-52. On TTIP, see Ferdi De Ville and Gabriel Siles-Brügge, TTIP. The Truth About the Transatlantic Trade and Investment Partnership (Cambridge; Malden MA: Polity Press, 2016).

3 On regionalism, see Bernard M. Hoekman and Michel M. Kostecki, The Political Economy of the World Trading System: The WTO and Beyond. 3rd edition (New York: Oxford University Press, 2010), 492-510. For the WTO's take on regionalism, see <http://www.wto.org/english/thewto_e/whatis_e/tif_e/bey1_e.htm> (Accessed: 14 Nov 2017). 
thus belie the narrative of Western decline due to the rise of other powers. TTIP triggered substantial civil society mobilization in the EU. ${ }^{4}$ As of 2017, the future of TTIP too is uncertain given that Trump has expressed a strong aversion to any kind of multilateralism in trade negotiations, including megaregionalism.

This does not mean megaregionalism will not become important again in the future, however, and then similar issues and questions will arise that have preoccupied friends and foes of these agreements. The basic rationale behind such treaties will inevitably reassert itself as the $21^{\text {st }}$ century progresses. In any event, the relationship between a potentially global multilateralism and the alternative prospect of a megaregionalism generates principled questions. For this reason, megaregionalism needs to be discussed from a standpoint of global justice, which is the purpose of this paper. For concreteness, and since it is possible that in the future that discussion will resume roughly where it was left, the focus is on TTIP and the state of negotiations for TTIP as they were towards the end of the Obama administration.

That megaregionalism could ever have emerged captures a deep crisis in global trade multilateralism that has arisen partly from an increasing unwillingness of weaker states to embrace whatever the powerful offer, and partly from the increasing digital divide in the world that undermines the extent to which partners in global trade have similar interests regarding regulation. My main objection to megaregionalism is that it diminishes the prospects of any kind of international trade arrangements to serve global justice. As opposed to the at least potential far-sightedness of multilateralism, megaregionalism stands for short-sightedness in the trade domain. The tendency of the overall assessment provided here specifically of TTIP from the standpoint of global justice is negative. It would be best if there will be no such treaty, certainly not outside of WTO multilateralism.

The remainder of this section talks some more about megaregionalism in general and TTIP in particular. Section 2 introduces the background view of global justice deployed here, the grounds-of-justice view originally developed

4 Opposition focused on the issue of investor-state dispute settlement (ISDS) clauses, which would give corporations the right to sue governments if their business interests are harmed by new legislation. In addition, there was public anger concerning data protection, health and environmental norms and standards, secrecy of the negotiations, as well as the possible impact on public services such as the National Health Service in the UK. A substantial share of the resistance was coordinated by NGOs and platforms in Germany. 
in my On Global Justice. ${ }^{5}$ Section 3 explores the implications of this view for a global trade organization, an ideal one and the real one. Section 4 explores issues concerning loss of democratic contestation as a consequence of TTIP. Sections 5 and 6 present my main point about megaregionalism. In all likelihood, megaregionalism is detrimental to global justice. TTIP in particular (or anything like it) might derail any possibility for a trade organization to aid the pursuit of justice at the global level, and any possibility that trade will be used to that end. From the standpoint of global justice one must hope that megaregionalism does not replace WTO multilateralism. Section 7 concludes. This negative assessment of TTIP draws on a mixture of conceptual and empirical reasons. In principle, WTO multilateralism and megaregionalism diverge; what is morally required is WTO-style multilateralism; it requires a certain factual constellation to reconcile multilateralism and megaregionalism; but this constellation seems not to be forthcoming.

Bilateral and regional treaties normally contain commitments on trade-related issues beyond what the WTO regulates. These agreements arose in response not merely to failures in WTO negotiations but also to the new complexities in trade from revolutions in information and communication technologies. These technologies make it possible for production stages that previously had to be performed in close proximity to be dispersed without much loss in efficiency. The WTO has not attended to these changes because it was 'otherwise occupied' with Doha. 6

Owing to thattechnological revolution, tradeingoods, internationalinvestment in facilities, training and technology, as well as use of infrastructure services for coordination have become closely intertwined. As a result, differences in regulatory regimes and rules relating to competition, investment, intellectual property and services across countries became more prominent than tariffs as obstacles to trade. By regulating that nexus between trade in goods, investment and use of infrastructure services, regional treaties aim to fill a governance gap. An agreement between the two largest economies that addresses that nexus, TTIP, if ever reinvigorated, could dramatically alter opportunities around the world.

5 Mathias Risse, On Global Justice (Princeton: Princeton University Press, 2012). Philosophical discussions of trade tend to be difficult because they come conceptually rather late. That is, many interconnected issues are in the air when we reflect on the morality of trade. Moreover, megaregionalism is a topic that would come conceptually late even within the domain of trade, the sort of topic one would discuss in a rather late chapter on a book on trade justice (and whose specifics one could actually expect to change due to an American presidential election or some such event). The forthcoming book by Risse and Wollner covers the issues at great length (and discusses megaregionalism in a rather late chapter). Sections 2 and 3 below will inevitably raise more questions than they answer, but they capture the vantage point from which megaregionalism is assessed here.

6 Richard Baldwin, '21st Century Regionalism: Filling the Gap between 21st Century Trade and 2oth Century Trade Rules', Staff Working Paper ERSD-2011-o8 (World Trade Organization: Economic Research and Statistics Division, 2011), p. 3 <https://ideas.repec.org/p/zbw/wtowps/ersd201108.html> (Accessed: 17 Nov 2017). 
TTIP was concerned with increasing access to products and services, including opening up government procurement practices (precluding, e.g., provisions in the 1933 Buy American Act directing procurement towards American products), but also about streamlining standards and regulation across industries such as car manufacturing, pharmaceuticals and financial services (terminating the necessity, e.g., for producers to conduct different safety tests), and about incorporating elements relevant to $21^{\text {st }}$-century commerce such as intellectual property, labor regulation, environmental rules and foreign direct investment.

In light of the fierce resistance some of its provisions have faced from civil society organizations especially in Europe it was unclear whether such a treaty could ultimately have been ratified or whether anything like it could be revitalized in the future even if the governments decided to resume the negotiations. The debate about TTIP was more vigorous in Europe than in the US during the final Obama years since the US public was preoccupied with TPP, to the extent that it cared about trade negotiations.

In any event, it is notoriously hard to predict any such treaty's impact (which is partly, though indeed only to a limited extent, what motivated resistance). Economic models quantify impact, making predictions about how many jobs would be created or lost, how much an average family would gain or lose, or what goods and services would fare better or worse once regulation changes. But using such models amounts to managing 'fictional expectations." ${ }^{7}$ After all, any change in trade rules not only affects parties currently involved in trade and how they do business; it also alters incentives for parties not currently connected to trade or motivate parties who are so connected to modify their business model. In response to any such changes yet other parties do things differently, and so on. Any model must build in assumptions about how such dynamic changes unfold. Since we are talking about reactions to reactions to reactions, such assumptions are fictional expectations. ${ }^{8}$ In light of such complications any philosophical (or for that matter, indeed any) discussion of issues arising from megaregionalism will have to be somewhat tentative in nature.

\section{The Grounds-of-Justice View and Trade}

This section and the next introduce the background material on justice based on which we then later assess megaregionalism. It lies in the nature of things that the brevity with which this material must be introduced here may lead to more questions than answers. To begin with, note that distributive justice is about making sure each individual has an appropriate place in what our distinctively

7 Jens Beckert, 'Imagined Futures: Fictional Expectations in the Economy.' Theory and Society 42/3 (May 2013), 219-40.

8 Dani Rodrik, Economics Rules: The Rights and Wrongs of the Dismal Science (New York: Norton \& Company, 2015). 
human capacities permit us to build, produce and maintain, as well as about being appropriately responsive to the sheer possession of these capacities. This, in any event, is a good way of capturing, at a certain level of abstraction, much of the discourse that went on under the heading of 'distributive justice' over the centuries.

In the Western tradition, we get our basic cues about how to think about justice from key passages in Plato and Aristotle. Plato's definition of justice as 'each doing / having his own' inspired many generations of thinkers to come up with variegated ways of conceptualizing what would count as 'their own.' Aristotle added a distinction between distributive and restorative justice, where the former was concerned with dividing what the polis owns in common. In Ancient Greece what the polis would own in common might include certain common possessions in the narrower sense, such as territories or booty taken in war. But what they had in common also included honors, according to Aristotle, which made clear that social constructs such as patterns of deferential behavior were from inception included in the purview of distributive justice. In Western thought, distributive justice never was merely about stuff, though it has become fashionable in recent philosophical discourse to dismiss the relevance of distributive justice precisely because it was allegedly too much concerned with stuff. ${ }^{9}$

A notion of social justice came into circulation only in the 19th century, as a response to the 'social question' that in turn theorized the abysmal conditions of the working class during the societal changes triggered by the Industrial Revolution. 'Social justice' insists each person get an appropriate share of what we produce together specifically in a state. At this stage discourse about justice has incorporated certain conditions not entailed by the original understanding of justice that came down to us from Plato and Aristotle and that, more generally, were not, certainly not broadly, accepted as part of the discourse about justice before the late 18th century: that each person matters, and matters in ways that includes care for material well-being; that giving people an appropriate share is practically possible rather than a pipe-dream; that it is for the state, rather than, say, churches to do so; and that any reasoning about how to go about this was based on secular justification. ${ }^{10}$

But such a notion of social justice, limited as it was to one country at a time, could ultimately not be stable in an intensely interconnected world. Matters of

9 For the argument that the relevant passages in Plato and Aristotle are the major points of orientation in Western discourse on justice, see Ernst Tugendhat, Vorlesungen über Ethik. 8th edition (Frankfurt am Main: Suhrkamp Verlag, 1993).

10 Samuel Fleischacker, A Short History of Distributive Justice. Revised edition (Cambridge, Mass.: Harvard University Press, 2005) 
distributive justice, that is, could not credibly be debated in a purely domestic manner. Ever since homo sapiens left Africa, several ten-thousand years ago, humankind has advanced in concert: goods, ideas, best practices have travelled fast across vast swaths of land. Over millennia, trade has in many ways made the world. In last 500 years, the formation of a single human web, an interconnected world society, has for better or worse been largely the outcome of European expansionism. One world culture has developed whose existence is often downplayed, for instance, in realist international relations theory. ${ }^{11}$

The recent work political philosophers have done in the global-justice domain is a much belated recognition of the instability of the notion of social justice as an account of distributive justice. Our economic context is global, our history is shared, and our environmental practices moved us into the Anthropocene. In light of these phenomena, On Global Justice offers an account of justice at the global level that embraces both the genuinely global dimensions of distributive justice and the complexity of contexts within which questions about distributive justice arise.

More specifically, in response to these phenomena I have proposed a theory of multiple grounds of justice. A ground of justice, technically, is a set of features of individuals that make it the case that especially stringent demands of distributive justice apply among these individuals. The grounds-of-justice approach proposes that there are several such grounds, and On Global Justice is concerned with five: membership in states; membership in the world society; subjection to the trading system; common ownership of earth; and common humanity. Respectively different principles of distributive justice are associated with these grounds, and a theory of global justice emerges from putting them together. This approach recognizes that particular principles of justice apply based on shared membership in a state. For this reason I refer to the grounds-ofjustice approach also as pluralist internationalism. I do so when what matters is to emphasize that - contrary to what various stripes of cosmopolitans assert - particular principles of justice hold for those who share a state while also stressing that there is a plurality of grounds of justice. Governments must take seriously obligations on all grounds. They cannot use obligations to the least advantaged in own country as an excuse.

Trade is one such ground, or more specifically, subjection to the existing trading system is. That trading system consists of the WTO and a number of

11 For the human-web terminology, see J. R. McNeill and William H. McNeill, The Human Web: A Bird's-Eye View of World History (New York: W. W. Norton \& Company, 2003). For the world-society approach, see for instance Georg Krücken and Gili Drori, World Society: The Writings of John W. Meyer (Oxford: Oxford University Press, 2010). On how trade has created the word, see William J. Bernstein, A Splendid Exchange: How Trade Shaped the World, 1st ed. (New York: Grove Press, 2009). 
regional trade regimes and treaties that together constitute an interconnected system of treaties and organizations that govern most of the world's trade. It requires substantial philosophical work to establish the grounds-of-justice view to begin with, and that trade is appropriately seen as one such ground. To see trade as a ground of justice means to accept that the activity of trading as such not only is subject to moral inquiry, but generates demands of justice that are not reducible to other concerns. For instance, trade does not merely matter from a standpoint of justice because it sometimes involves, say, human rights violations.

To say trade is a ground of justice implies that there is a principle of distributive justice associated with it. Again it requires substantial philosophical work to ascertain what this principle is. Aaron James, for one, might agree with much of what has been said so far but then argue that distributive justice in the trade domain requires that all gains from trade, above what participating countries can secure for themselves in autarky, be distributed equally among them. ${ }^{12}$ But as opposed to that, I submit that the principle of distributive justice associated with trade is this: the distribution of gains from global trade is just only if these gains have been obtained without exploitation. Trade injustice consists in exploitation involving the basic rules of the international trade regime. Exploitation itself is a multifaceted notion capturing different types of unfair advantage-taking that could include violations of reciprocity, of respect, of a duty of beneficence, of rights; and others more. A convincing account of exploitation must do justice to its multifaceted nature. ${ }^{13}$

A range of agents have obligations in the domain of trade, including individuals, states and corporations. In virtue of being such powerful agents states have the primary responsibility for realizing all principles of justice that apply to them. But one needs partners to trade. Continued interaction presupposes international market reliance practices. The economic rationale for trade is often made in a unilateral manner: it makes sense for each country, say, to figure out what they are good at, specialize in that product, and obtain other things by trading them for that product. But it takes an international regime to make trade safe and reliable. ${ }^{14}$ States have trade-related obligations of justice because they are actors within that ground. However, these are not obligations they have on their own, but share with other states involved with the trade regime. Acceptance of trade-related obligations must involve a burden-sharing arrangement.

12 Aaron James, Fairness in Practice: A Social Contract for a Global Economy (New York: Oxford University Press, 2012).

13 Developing such an account of exploitation is where my ongoing work with Gabriel Wollner goes beyond the work on trade done in On Global Justice. The latter work did not say enough about trade; see Risse (2012), ch. 14.

14 This is a point forcefully made by James (2012). 


\section{The Ideal Global Trade Organization, and the Real One}

Political scientists - who see the partially conflictual nature of trade more clearly than economists, who emphasize the rationality of trade for each actor - emphasize the 'logic of multilateral trade liberalization' as the need for a mechanism that allows states to make commitments to avoid retaliatory trade wars. ${ }^{15}$ Parallel to this political-scientific argument we can make the moral argument for the international trade organization as providing a forum for states to make commitments reflecting their shared moral obligation in the trade domain. Given the globally interlocking nature of trade, and given that there should be an international organization concerned with trade, there should be one global such organization, rather than several regional ones. ${ }^{16}$ Since in our world there already is such an organization with global ambitions, that organization - the WTO - should be reformed to be an agent of justice.

Since such an organization would be (and the actual one has been) founded by states it inherits obligations from states. What should follow is a discussion of what obligations remain in immediate care of states and which ones are bequeathed to that organization. To the extent that the nature of the obligation calls for an international organization, those obligations should be transferred to it. Since in the case of trade we talk about globally interlocking activities, the presumption is that most trade-related obligations would be in the care of that organization. Its treaty framework would regulate the basic parameters of trade in a manner that is non-exploitative. But in any event, all the relevant obligations are ultimately obligations of states.

Since the trade organization is to be founded by states for certain purposes, those purposes primarily determine its obligations. But the organization also inherits other justice-related obligations by which states are bound already. In particular, both common humanity and membership in the world society generate human-rights-related obligations that apply to states. Since the view of human rights that is part of pluralist internationalism implies a duty of assistance in building institutions, the WTO also has a development-oriented mandate that derives from this human-rights-oriented mandate. ${ }^{17}$ To the extent that many people continue to think of the WTO as mostly or exclusively an entity concerned with liberalizing and administering trade in a manner that is not generally connected to such further-reaching goals, I submit we must collectively rethink the obligations of the global trade organization.

15 Amrita Narlikar, The World Trade Organization: A Very Short Introduction. (New York: Oxford University Press, 2005), p. 5. For a more extended version of the argument, see Robert E. Baldwin, 'The Case For a Multilateral Trade Organization', in Martin Daunton, Amrita Narlikar, and Robert M. Stern (eds.), The Oxford Handbook on The World Trade Organization (Oxford: Oxford University Press, 2012), 29-39.

16 That same reasoning may not apply to an organization concerned with development. In that domain, one could argue that more than one organization might be appropriate, see Risse (2012), pp. 357-8.

17 For the duty of assistance and its connection to common humanity as a ground, see ibid., ch. 4. 
Needless to say, the trade organization ought to prioritize trade justice but human rights also constrain and guide how the organization pursues trade justice. Human rights constrain in the sense that the organization is not supposed to pursue trade justice at the expense of human rights violations. Human rights guide if trade arrangements are used suitably in pursuit of human rights causes. For example, Christian Barry and Sanjay Reddy explore ways in which the WTO could help implement a link between trade and labor standards. Such linkage is desirable because it creates incentives for governments to improve labor standards. Trade would be conditional upon promotion of labor standards. My argument supports such linkage. More generally, my argument supports proposals to make trade conditional upon promotion of human rights and eschewal of tainted gains from trade - unless there is evidence that doing so would backfire and make these goals less likely to be realized rather than more. ${ }^{18}$

Alas, the WTO does not see itself, and is not seen by observers, as an agent of justice. Instead, in the WTO's view, 'the trade system's overriding purpose is to help trade flow as freely as possible - so long as there are no undesirable side effects - because this is important for economic development and well-being. ${ }^{19}$ Nonetheless that organization becomes the obvious target of reflection from a standpoint of trade justice. The trade organization needs to be reoriented so justice becomes a primary goal rather than something that may or may not emerge through market liberalization. ${ }^{20}$ That is, the argument that states ought to found an organization to pursue trade justice translates into an argument for a thorough reform of the existing organization. Alternatively, one could support the founding of a new organization altogether. But if arguments for reforming the current one fall on deaf ears then so will arguments for a new organization, and more so.

It is often said a 'grand bargain' was struck between developed and developing

18 Christian Barry and Sanjay G. Reddy, International Trade and Labor Standards: A Proposal for Linkage (Columbia University Press, 2008). For more discussion on the link between labor rights, human rights and global justice, see the set of papers in Yossi Dahan, Hanna Lerner, and Faina Milman-Sivan (eds.), Global Justice and International Labour Rights (Cambridge, United Kingdom; New York: Cambridge University Press, 2016).

19 <https://www.wto.org/english/thewto_e/whatis_e/who_we_are_e.htm> (Accessed: 13 March 2017).

20 Wilkinson makes a similar point in terms of social goods rather than justice, see Rorden Wilkinson, What's Wrong with the WTO and How to Fix It (Cambridge; Malden, MA: Polity, 2014). For a competing view on this matter, see Andrew G. Brown and Robert M. Stern, 'Concepts of Fairness in the Global Trading System', Pacific Economic Review 12/3 (2007), 293-318. They argue that, as far as justice is concerned, the global trading system is merely an arrangement to further mutually advantageous commercial relations between countries. 
countries when the actual WTO was established in $1995 \cdot{ }^{21}$ Developing countries would accept a 'single undertaking' - meaning all members must accept the treaty as a whole, rather than be allowed to exempt themselves from some provisions - that included a wide range of rules and commitments restricting the policy space to deploy developmental measures. Some such rules and commitments covered new areas, such as services and of intellectual property. Both domains of regulation allowed developed-country industries to expand deeply into developing-country markets. In return, developed countries would open up in areas of interest to developing countries such as agriculture and textiles.

In some ways the WTO regime has held up well. Countries have mostly refrained from raising trade barriers during financial crises. Moreover, the dispute settlement system is highly regarded; it is much-strengthened vis-àvis the the General Agreement on Tariffs and Trade's (GATT's) and permits sanctions against violators. But compared to the more forceful postwar proposals to integrate developing countries into the trade system the spirit of the WTO is to let developing countries have some share of globalization in return for playing by rules that mostly maintain market access for developedcountry industries. Accordingly, there is a widespread sense that the WTO has not worked to the benefit of the poor.

Despite lack of implementation of the developed countries' side of the bargain, particularly in agriculture, new negotiations commenced in 2001 in Doha. ${ }^{22}$ The Doha round is commonly called a development round. The negotiations have been contentious. The conflict between free trade on goods and services and some developed countries' insistence on retaining agricultural subsidies, have

21 On the WTO, see Craig Van Grasstek, The History and Future of the World Trade Organization (Geneva, Switzerland: World Trade Organization, 2013); Hoekman and Kostecki (2010), ch. 2; Gilbert Winham, 'Explanations of Developing Country Behaviour in the GATT Uruguay Round Negotiation', World Competition Law and Economics Review 21 (1998), 109-34, ch. 1; Wilkinson (2014), ch. 1; Amrita Narlikar, Martin Daunton and Robert M. Stern, The Oxford Handbook on the World Trade Organization (New York: Oxford University Press, 2012). For the history of the trade system under political aspects, see John H. Barton, Judith L. Goldstein, Timothy E. Josling, and Richard H. Steinberg, The Evolution of the Trade Regime: Politics, Law, and Economics of the GATT and the WTO. (Princeton, N.J.: Princeton University Press, 2008). For a short introduction, see Narlikar (2005).

22 On the Doha round, see Vinaye Ancharaz, 'Can the Doha Round Be Saved?', in Meléndez-Ortiz, Bellmann, and Mendoza (2012), 119-29; Donna Lee and Rorden Wilkinson (eds.), The WTO after Hong Kong: Progress In, and Prospects For, the Doha Development Agenda. New Edition (London; New York: Routledge, 2007); Hoekman and Kostecki (2010), 140-46. For the WTO's own take on the Doha agenda, see 'The Doha Agenda', World Trade Organization, <https:// www.wto.org/english/thewto_e/whatis_e/tif_e/doha1_e.htm> (Accessed: 25 October 2016). See also Cédric Dupont and Manfred Elsig, 'Persistent Deadlock In Multilateral Trade Negotiations: The Case Of Doha', in Martin Daunton, Amrita Narlikar, and Robert M. Stern (eds.), The Oxford Handbook on The World Trade Organization (Oxford: Oxford University Press, 2012), 587-606; Kent Jones, The Doha Blues: Institutional Crisis and Reform in the WTO (Oxford; New York: Oxford University Press, 2009). For some minor breakthroughs in Bali in 2013, see Rorden Wilkinson, Erin Hannah, and James Scott, 'The WTO in Bali: What MC9 Means for the Doha Development Agenda and Why It Matters', Third World Quarterly 35/6 (2014), 1032-1050. Regarding the need for a development round and the early years of Doha, see also Joseph E. Stiglitz and Andrew Charlton, Fair Trade for All: How Trade Can Promote Development (Oxford University Press, 2007), ch. 3-4. 
remained major obstacles. As of the time of this writing, no major breakthrough has been achieved. The fact that Doha has so far failed to offer a meaningful place with the trade regime to developing countries is symptomatic of underlying problems about asymmetrical capacities to take advantage of the system. But the duration of the negotiations also reveals that developing countries are unwilling to accept just any arrangements offered by the powerful players. ${ }^{23}$

According to the account of trade justice developed in the forthcoming book by Gabriel Wollner and myself, the charge that 'the WTO has not worked to benefit of the poor' translates into a charge of exploitation. The WTO is exploitative because its structure and decisions reflect that it does not take seriously enough its development - and human-rights - oriented mandates. Accordingly, the best way of thinking about reforming the WTO from a justice-based standpoint is to take far-reaching measures that would make it take this mandate more seriously. There is not enough space here to substantiate this judgment with the appropriate philosophical rigor. But saying this much should suffice for purposes of this paper.

\section{TTIP and the Value of Democracy}

Let us now inquire about the threat to democracy posed by TTIP. Note first that, once we see that justice is multifaceted and global in nature, we must also realize that this will have consequences for our understanding of democracy. Since governments have obligations of justice not limited to those who get to vote, they must also give account for what they do about certain obligations of

23 It should be noted though that some important progress has at least been made with regard to agricultural subsidies, a highly contentious subject matter for decades. As the OECD notes, the 50 countries covered by its annual agricultural policy reports (and that account for the majority of the world's agricultural value added) provided an annual average of USD 585 billion of support directly to agricultural producers in the years 2013-15, and an additional USD 87 billion on general services supporting the sector; see OECD, 'Agricultural Policy Monitoring and Evaluation 2016,' p 25. It has long been recognized that how countries support farmers is as important as the total level of support. On average for the 50 countries covered, $68 \%$ of support to farmers was provided in the form of market price support, payments based on output or on input use without constraints. It is these measures that can significantly distort markets and trade, and it is therefore these measures that have increasingly come under scrutiny. For OECD countries as a whole, support has roughly halved in intensity over the past 30 years. At the same time, average support levels in emerging economies have increased from low or even negative levels to approaching the average level of OECD countries; see ibid., 25. In 2015, governments at the UN adopted seventeen Sustainable Development Goals as part of the Agenda 2030. Better functioning markets for food and agriculture are integral to this vision. Governments agreed, to 'correct and prevent trade restrictions and distortions in world agricultural markets' (language from Goal 2b, see United Nations, Transforming our World: The 2030 Agenda for Sustainable Development; <https://sustainabledevelopment. un.org/content/documents/21252030\%20Agenda\%2ofor\%20Sustainable\%20Development\%20web.pdf> (Accessed: 3 May 2017). In December 2015, members of the WTO agreed to eliminate agricultural export subsidies at the global trade body's Nairobi ministerial conference. For the current state of debate on these matters as of 2017, see OECD, Agricultural Policy Monitoring and Evaluation 2016 (OECD Publishing, Paris, 2016); ICTSD, Negotiating Global Rules on Agricultural Domestic Support: Options for the World Trade Organization's Buenos Aires Ministerial Conference. Geneva: I (Geneva: International Centre for Trade and Sustainable Development (ICTSD), 2017). Also, over the last decade the World Bank has conducted an extensive research program to assess the distortions arising from agricultural subsidies in different regions of the world; see <http://econ.worldbank.org/WBSITE/EXTERNAL/ EXTDEC/EXTRESEARCH/EXTPROGRAMS/EXTTRADERESEARCH/o,,contentMDK:21012395 pagePK:6416818 2 piPK:64168060 theSitePK:544849,oo.html> (Accessed: 3 May 2017). 
justice to people who do not get to vote for them. Such accountability would presumably have to occur in international organizations. To the extent that it does, democratic decision making is constrained: as a matter of justice, voters do not have a conclusive say over everything the government does. In any event, some losses to democracy are inevitable in a globalizing world that continues to be a world of states. From the standpoint of justice certain losses in domestic contestation are acceptable and even called for. ${ }^{24}$

But these conclusions leave much to be discussed about the domains where such losses would be incurred, and what kind of rule-making should be in place when the rules are not made by domestic democracy. From the standpoint of trade negotiations everything that hampers trade readily looks like a mere regulatory obstacle, much as some economists even think of the existence of citizenship itself as an obstacle to the functioning of labor market. ${ }^{25}$ The resulting proposals for deep integration (like TTIP) remove certain domains from their previous oversight, for the sake of increasing trade flow and in the expectation of greater revenues that hopefully not only accrue to a selected few.

But it behooves us to be careful that the shape of the world is not left entirely in the hands of trade representatives. One may be reminded of a powerful passage from the Communist Manifesto:

The bourgeoisie, wherever it has got the upper hand has put an end to all feudal, patriarchal, idyllic relations. It has pitilessly torn asunder the motley feudal ties that bound man to his 'natural superiors', and has left remaining no other nexus between man and man than naked self-interest, than callous 'cash payment'. It has drowned the most heavenly ecstasies of religious fervor, of chivalrous enthusiasm, of philistine sentimentalism, in the icy water of egotistical calculation. It has resolved personal worth into exchange value, and in place of the numberless indefeasible chartered freedoms, has set up that single, unconscionable freedom - Free Trade. ${ }^{26}$

Times have changed since Marx and Engels wrote these lines in the 1840s. Still, underlying concerns about the acceptability of trade's transformative

24 The connection between justice and accountability is developed in detail in Risse (2012), chs. 17-18. For discussion about why giving up on states altogether and making democracy global is not the answer, see ibid., pp. 15-16. For the inevitability of losses to democracy in a globalizing world that continues to be a world of states, see Dani Rodrik, The Globalization Paradox: Democracy and the Future of the World Economy. Reprint edition (W. W. Norton \& Company, 2012), ch. 9.

25 De Ville and Siles-Brügge (2016)'s main conclusion about TTIP is this: 'It is driven by both a philosophy and a discourse that idealize the efficient operation of markets and seek to minimize the constraints imposed by democratic decision-making in public policy, which is seen as inherently susceptible to capture by special interests and hence inefficient policy outcomes', p. 131.

26 David McLellan (ed.), Karl Marx: Selected Writings (Oxford: Oxford University Press, 1977), pp. 247-8. 
power persist, and reemerged in reactions to TTIP. Despite much convergence in lifestyle between Europe and North America there are significant differences: public services play a larger role in Europe; labor markets work differently, with American markets lacking the rigidity characteristic of European ones; there are different risk cultures, with Europeans more focused on ex ante assessments and precautionary thinking. These are not just matters of administrative convention but deeper differences in societal values. The Marx-and-Engels passage warns of the erosion of such societal values through trade.

At the same time, there are special interest groups that may find it convenient to appeal to societal values, and much regulation indeed is a matter of administrative convention that might as well be settled differently. So a careful look and a political decision is necessary to distinguish matters of genuinely deep societal concern from those that could be modified without much of a threat to broadly cherished values. To mention one domain where modifications would be unproblematic from the standpoint of the value of democracy, EU and US do not recognize many of each other's safety regulations. For instance, US and EU require different crash test dummies for car safety tests, even though the dummies accomplish the same goal. Manufacturers must do the same test twice, which increases prices noticeably. A similar story is true for tests on chemicals. $^{27}$

But matters are different for food and environmental standards. One issue is whether the EU would admit genetically modified products. EU countries that value their agriculture highly loath changing policies, especially if the EU's high production standards come under siege. The US makes it easy for companies to add untested ingredients to products if scientific results fail to cause alarm. The EU's precautionary approach pushes into a different direction. In Europe concerns about genetically modified food are widespread and capture deeplyheld attitudes. ${ }^{28}$ To illustrate, in the famous Beef-Hormone Case where use of certain hormones for cattle-raising was at stake, the WTO found against the EU, but the EU persisted in banning hormone-treated beef and received retaliatory measures rather than comply with that decision. ${ }^{29}$ Importantly, also, European reliance on fossil fuels will likely increase, and pressures on finding alternative sources of energy soften, if it becomes easier for the US to export its abundance of shale gas.

Problematic changes in domains where broadly shared societal values are at

27 See for instance <http://www.bbc.com/news/uk-politics-30493297> (Accessed: 19 May 2017).

28 In spite of such difference there is also a fair amount of convergence before the background of which exceptional areas stand out; for a systematic study of different risk regimes, see Christopher Hood, Henry Rothstein, and Robert Baldwin, The Government of Risk 'Understanding Risk Regulation Regimes' (New York: Oxford University Press, 2001).

29 For the Beef Hormone case, see Hoekman and Kostecki (2010), pp. 105-7. 
stake might also come over time. To the extent that TTIP would move decisionmaking away from domestic democracy and into channels where corporations have a larger say it might cause a long-term chilling effect on regulation and protection. The depoliticization of regulatory decision-making might well make it easier to deregulate in the long run, and more difficult to adopt ambitious policies to improve the environment, health or working conditions. ${ }^{30}$

In addition to the question about the domains where domestic democracy may want to insist on its decision-making capacities there is the question of what new forms of decision-making would become operative. One worry is about investor-state dispute settlement (ISDS). ISDS is an instrument of public international law that grants investors rights to use dispute settlement proceedings against foreign governments. Suppose an investor from one country invests in another, both of which have agreed to ISDS. If that other country violates rights granted to the investor, she may bring the issue before an arbitration tribunal. The motivation for ISDS is to protect investors from capricious policy-changes going as far as expropriation. To that effect, the tribunals deciding on the matter are staffed with decision makers that are decidedly not accountable to the government in question. However, concerns arise about the kind of accountability under which such tribunals operate and about the possibilities corporations may have to exercise control over the selection of key decision makers.

Provisions for ISDS are contained in many investment - and trade - related treaties. States may well have reasons to agree to such protection to attract investment that otherwise would not occur. Such a commitment would not prevent states from changing policies later: they simply have to pay compensation as they agreed to as a condition of the investment. In principle there is nothing wrong with deploying such tools, setting aside concerns about the underlying assumption that investment would otherwise be hampered. However, investor protection can inhibit the capacity of governments to pass new legislation if investors can extract prohibitively high compensation. This would be most challenging for developing countries that have not yet implemented health and environmental protection, labor rights or human rights. Such countries might find themselves in the awkward situation of compensating investors for loss of revenue if they decide to take such measures.

30 (1) On this topic, see De Ville and Siles-Brügge (2016), ch. 3. TTIP would also put the different varieties of capitalism operative in the US and Europe into competition with each other. The EU might well lose jobs because the less rigid nature of the American job market makes it enticing for companies to move key functions across the ocean. Trading products back to Europe would be easy. <https://oppex.com/blog/is-ttip-agreement-an-advantage-or-disadvantagefor-european-companies/> (Accessed: 1 April 2017). 
All this would be unproblematic in the context of EU and US, however, where even the worst-case scenarios would do no serious damage to regulative and legislative options. But overall ISDS is a legal instrument that should be abandoned. Even if concerns about lack of accountability of arbitration panels could be resolved, problems would remain. For one thing it is unwise for governments to give foreign companies possibilities domestic companies do not have (to demand compensation for policy changes). To this point one might say it could also be read as a push towards extending the same prerogative to domestic companies rather than denying them to foreign ones. But why not then insure all individuals too (both citizens and foreigners) against policy changes?

More importantly, ISDS creates much potential for exploitative situations between corporations based in developed countries, on the one side, and developing countries where they operate, on the other. The more ISDS becomes entrenched, the more developing countries come under pressure to endorse them also in the next treaty. Perhaps there is a way of formulating investor protection so that it does not prevent developing countries from improving health and environmental protection, labor rights and human rights. But since investor protection is geared towards maintaining the status quo under which investment decisions are made, this might be tantamount to squaring the circle. In light of today's power differentials the need of developing countries to have policy spaces protected outweighs the need of corporations to be protected against capricious policy changes. By way of concluding our assessment of ISDS, I can only agree with the following statement by the United Nations Conference on Trade and Development (UNCTAD):

If the reason for establishing ISDS is to respond to failures in national judicial systems that do not provide independent justice or enforce the protection of private property, the appropriate response should be to fix those shortcomings, rather than allowing foreign investors to seek justice elsewhere. ${ }^{31}$

If concerns about domestic democracy were the only pertinent issues (specially about TTIP) solutions could probably be found. After all, there are good reasons to restrict domestic democratic contestation anyway. A helpful thought is to regard TTIP or other such treaties as a 'living agreement' to which sectorial annexes might subsequently be added under parliamentary

31 United Nations Conference on Trade and Development (UNCTAD), Trade and Development Report, 2014 - Global Governance and Policy Space For Development (New York and Geneva: United Nations, 2014). <http://unctad.org/ en/PublicationsLibrary/tdr2014_en.pdf>, p. 146. 
oversight. ${ }^{32}$ Moreover, even those areas where concerns about the value of domestic democracy are at their most plausible might have to be reconsidered if TTIP advanced global justice. Alas, the opposite is true. From the standpoint of global justice, TTIP in particular and megaregionalism generally move in the wrong direction. It becomes questionable that even a version of TTIP should be concluded at some point in the future that focuses merely on low-hanging fruit (e.g., safety-tests). If the price for such economic advantages is a strengthening of megaregionalism, it is too high.

\section{Megaregionalism and Global Justice in Light of a Possible Failure of the Doha Round}

Most of the discussion about TTIP, as about other bilateral and regional agreements, occurred from the standpoint of potential participants. The guiding question tended to be how any agreement affects them. How much growth would it generate for the US, Germany, Slovenia, or the EU as a whole? How would it affect particular niches? Or how would it affect certain countries outside the EU and US?

As opposed to that, one major concern from the standpoint of global justice is how the emergence of megaregionalism could affect the future of multilateralism. Earlier we noted that there is a justice-based rationale for the existence of a trade organization with global reach. The current WTO is far from having all credentials it should have from a standpoint of justice. But at least it is an organization with global aspirations whose preamble contains moral language. Both the increase in membership in recent years and the manner in which the WTO has integrated countries beyond those in the narrow club of wealthy countries that used to set the global trade agenda in principle bode well for the WTO's potential as a global organization that could take seriously obligations of justice. There is of course a long way to go still. The current WTO is exploitative in the lights of the grounds-of-justice approach. However, at least in light of its genuinely global aspirations that organization is an enormous step into the right direction. Megaregionalism threatens all of that. Instead of reforming the WTO to be an agent of justice megaregionalism dismantles its critically important multilateralism.

32 'If well-handled,' Alemanno, writes, 'the innovative mechanisms of international cooperation envisioned in TTIP carries the potential to establish a transatlantic regulatory laboratory. (...) [I]ts success will largely be determined by its ability to connect this mechanism to the existing regulatory cooperation and ensure parliamentary input into its operation so as to guarantee TTIP's legitimacy and accountability;' (Alberto Alemanno, European Parliament, and Directorate-General for External Policies of the Union, The Transatlantic Trade and Investment Partnership and the Parliamentary Dimension of Regulatory Cooperation 6 (Brussels: European Parliament, 2014), <http:// www.europarl.europa.eu/RegData/ etudes/etudes/join/2014/433847/EXPO-AFET_ET(2014)433847_EN.pdf> (Accessed 14 November 2017).). See also Sebastian Dullien, Adriana Garcia, Josef Janning, and European Council on Foreign Relations, A Fresh Start for TTIP (2015), <http://www.ecfr.eu/publications/summary/a_fresh_start_for_ ttip330> (Accessed: 14 Nov 2017). 
Megaregionalism has been largely a response to Doha's looming failure. Such a failure would cast shadows over the WTO's ability to be a global organization concerned with justice. A breakdown of Doha would derail the WTO's efforts to test its capacities as a development-oriented organization. It would be a failure in its efforts to provide benefits to developing countries in response to their struggles to adjust to burdens they accepted under the WTO beyond what was expected under the GATT (especially in intellectual property regulation). The issues continue to be reform of agricultural subsidies; assurances that additional liberalization in the global economy respects the need for sustainable growth in developing countries; and improved access to global markets for export. That these issues could not be resolved so far also reflects the WTO's more inclusive nature, making it impossible for traditional powers to settle matters to their liking without much further ado (especially as far as agriculture is concerned). But it has also become clear that the organization continues not to work for the benefit of less advantaged economies.

A breakdown of Doha accompanied by strengthened megaregionalism might render global multilateralism increasingly irrelevant. WTO members comply with existing agreements partly because they hope for new ones that will benefit them. But such an expectation presupposes that the WTO remains capable of generating agreements to begin with. Moreover, so far no deep preferential arrangements have been made among the largest trading blocks, the US, EU, China, Brazil and India. To the extent that that has not happened yet, the WTO, the principal meeting point for these countries, has not lived up to its purposes. If they cannot arrive at further-reaching agreements under the WTO's auspices these countries might end up making more arrangements outside of the WTO, further weakening its potential.

One might say regional trade arrangements themselves could advance global justice, in two ways. First of all, regional arrangements could be sensitive to obligations that I argued accrued to a global organization. Perhaps regional blocks accept development - and human-rights - oriented mandates. But that is unlikely. After all, the most powerful regional arrangements that have so far been on the agenda or are likely to return to it - especially one between the US and the EU - fail to include poor countries. If it is practically impossible to reach agreements to benefit poor countries within an institutional setting that includes them, prospects are dim that this would be so within a setting that does not - especially if that new setting has come about in the first place because of failures to respond to needs of such countries. More likely, regional blocks become inward-looking and disregard duties towards non-members. If 
multilateralism fails to work for poor countries, megaregionalism is not going to do so. ${ }^{33}$

A second possibility is that, as proponents argue, TTIP (or related treaty that might be proposed in the future) in particular might inaugurate new global standards. If the WTO itself disintegrates as a forum for negotiating such standards, perhaps the largest economies should be torch-bearers of progress. Eventually others will adopt the same standards. But consider two responses. First of all, the largest economies would then have a first-mover advantage in establishing rules and standards others later will have little prospect of renegotiating. They have to comply, as well as presumably shoulder all costs of adjustment, without having any say in the design of regulation. However, and this is the second response, prospects that TTIP would even aspire at ushering in global standards seem remote. Setting aside concerns about that very role, TTIP could be such a torch-bearer only if it were concerned with harmonization rather than mutual recognition. There are important differences between those two.

Harmonization involves deliberation about which of two sets of rules to adopt, perhaps also the decision to discard both in favor of a third. Going through something like this could be an earnest exercise pondering lessons learned from past standard-setting and regulation. But this would be a labor-intensive process and put the whole costs of adjustment in the particular domain on the block asked to make changes while imposing no costs on the other. As opposed to harmonization, mutual recognition would mean both US standards and regulations and those valid in the EU could be adopted. Businesses on both sides of the Atlantic would be free to choose either, as suits their interests. Mutual recognition differs substantially from harmonization: it involves no serious deliberative exercise, but delegates all decision-making to companies and thus renders it a purely economic choice.

One might think the concern about harmonization imposing unilateral burdens is alleviated if one trade area adjusts to one set of standards and the other to a different set; and then there would be a third domain where both adjust because they realize there are improvements over current regulation in

33 For the point that despite its shortcomings, multilateralism is the best available option for economically weaker countries, also see Darrel Moellendorf, 'The World Trade Organization and Egalitarian Justice', Metaphilosophy 36/1-2 (2005), 145-162. UNCTAD has argued that 'developing countries require greater policy space to enable them to continue their rapid growth trajectory of the past 15 years and make such growth more equitable and sustainable. Strengthened global economic governance that refocuses trade negotiations on multilateral agreements which recognize the legitimate concerns of developing countries, abandons WTO-plus and WTO-extra provisions and fosters the developmental character of the Doha Round would be an important step in this direction. Leveraging the greater economic and political power that developing countries have achieved over the past two decades could strongly support this process;' United Nations Conference on Trade and Development (UNCTAD), Trade and Development Report, 2014 - Global Governance and Policy Space For Development, 80. 
either system. But that version of harmonization too would be a highly laborintensive exercise, and thus come with the all the political intricacies of seeing through such efforts. Accordingly, before their suspension upon Trump's inauguration mutual recognition is where the negotiations about TTIP were headed. The European Commission was explicit about this, hoping to 'help EU and US regulators work more closely when setting new regulations' and 'recognize each other's regulations where they provide equivalent protection.'34

Mutual recognition in turn might either be limited to businesses in the US and EU, or be extended to everybody. On the latter model countries outside of these trade blocks could choose to follow either the US or the EU approach. In the former case companies in third countries would suffer serious competitive disadvantages because they must continue to produce for both markets whereas competitors in the domain ruled by TTIP could choose standards. Third countries would have little reason to adjust to either standard and might not be able to prevail on the new transatlantic mega-market. TTIP would have no chance of being a gateway to new global standards. ${ }^{35}$

But even if third countries did get to reap the benefits of mutual recognition we would still be no closer to global standards. To that effect we would need harmonization rather than mutual recognition. And even if we did have harmonization, it would be the kind of harmonization that gives first-mover advantage to leading trade nations and would leave to others merely the option of joining or not joining. ${ }^{36}$

\section{Megaregionalism and Global Justice: General Concerns for the Future}

So far we have assumed megaregionalism poses a problem only if Doha fails. But megaregionalism threatens the role of the WTO even in the unlikely event that Doha succeeds at generating agreements acceptable to developing countries. The looming breakdown is not the only reason we see an increasing number of regional treaties. The other is that 21st century trade - unfolding in the aftermath of the recent technological revolution - creates pressures on the rule-writing front (much more so than on the tariff-cutting front). ${ }^{37}$ One

34 See <http://ec.europa.eu/trade/policy/in-focus/ttip/about-ttip/questions-and-answers/> (Accessed: 29 March 2016). See also De Ville and Siles-Brügge (2016), ch. 2.

35 Ibid., chapter 2 argue that, based on their interviews with negotiators and their acquaintance with position papers, a bilateral limitation of mutual recognition was more likely than giving companies in third countries the same choice.

36 For the topics in the last several paragraphs, see De Ville and Siles-Brügge (2016), ch. 2.; for mutual recognition in governance generally, see Susanne K. Schmidt, 'Mutual Recognition as a New Mode of Governance', Journal of European Public Policy 14/5 (August 2007), 667-81; Kalypso Nicolaidis and Gregory Shaffer, 'Transnational Mutual Recognition Regimes: Governance without Global Government', Law and Contemporary Problems 68/3-4 (2005), 263-317; Joel P. Trachtman, 'Embedding Mutual Recognition at the WTO', Journal of European Public Policy 14/5 (August 2007), 780-99.

37 Baldwin, Richard (2011) 
way the WTO might become irrelevant is if groups of countries (e.g., EU and US, in the case of TTIP) find it more congenial to reach agreement with each other without bothering to make efforts under the aegis of the global trade organization. Success at Doha would then turn out to be Pyric, a consolation prize for developing countries upon the award of which developed countries attend to the remaining agenda exclusively in each other's company. It is also for this long-term structural reason that megaregionalism is very likely to return to the agenda of international politics, its hiatus under Trump notwithstanding.

Insisting that megaregionalism has come to stay, Lawrence (2012) thinks one way of domesticating it is to fold plurilateral treaties into the WTO framework (i.e., treaties that do not involve all members). ${ }^{38}$ Differential needs of economies would be recognized within the system to avoid collapse. Supplementing core WTO obligations with plurilateral agreements could promote deeper integration (first regionally, then perhaps globally) while alleviating institutional tensions. This could be a compromise to let diversity co-exist with more extensive commitments among the willing. But ultimately this too would be resignation as far as multilateral ambitions and global obligations of justice of the global trade organization are concerned. It requires much optimism to think problems about regionalism outside of the WTO can be resolved by transforming megaregionalism into plurilateralism within the organization.

If megaregionalism has come to stay, this would in all likelihood be bad news for global justice. I argued earlier for a reconsideration of the WTO as an organization with a human-rights - and development - oriented mandate. Let us finish this discussion with that same thought, this time quoting from Wilkinson (2014), who also thinks the WTO must be thoroughly reconsidered:

A new declaration of aims and objectives ought to place the realization of trade-led development-for-all in an environmentally sustainable fashion at the forefront of the purposes of the multi-lateral trading system with particular emphasis on helping the least able. ${ }^{39}$

\section{Conclusion}

In all likelihood megaregionalism is detrimental to global justice. TTIP in particular would have the potential of derailing any possibility that a trade organization could pursue justice at the global level, and indeed any possibility that trade will be used to that end. From the standpoint of global justice one can

38 Robert Lawrence, 'Competing with Regionalism by Revitalizing the WTO', in Meléndez-Ortiz, Bellmann, and Mendoza (2012), 38-41.

39 See Wilkinson (2014), ch. 6, for thoughts on how to go about this (quotation from p. 143); see also Clive George, The Truth about Trade: The Real Impact of Liberalization (London; New York; New York: Zed Books, 2010), ch. 10. 
only hope that megaregionalism will not become entrenched to replace WTO multilateralism.

There is a possible scenario under which megaregionalism advances global justice. For this reason I state my conclusion as true 'in all likelihood.' That would be if the negotiations selected sensible standards and regulation the rest of the world has good reason to accept. But if things will end up going that way, this would be as splendid an appearance of the cunning of reason as one can think of, a cunning that would work in support of global justice even though the particulars of the negotiation process and the putative aims of the relevant parties do not.

But a bet on the cunning of reason is usually a bad bet. In this case, the workings of megaregionalism would have to support the multilateralism required by global justice even though megaregionalism by design is a retreat from a genuinely global orientation. Conceptually there is a deep tension only a particular alignment of facts could resolve, which empirical research does not tell us is present. In light of the damaging prospects of megaregionalism one should even reject a version of TTIP that merely reaches for low-hanging fruit. Accepting such an agreement would likely have chilling effects on future possibilities of multilateralism. It would be a step in the wrong direction.

Plurilateralism within the WTO, under the circumstances, would be the distinctively second-best outcome. Plurilateralism would most likely indicate that the global trade organization fails to move into the direction I have argued is required from the standpoint of global justice. Plurilateral agreements under the auspices of the WTO do many benefits in comparison to deals negotiated outside the multilateral system, including transparency and options for all member states to join the negotiations. This path might eventually be the only way to keep trade negotiations within the WTO alive. So at least plurilateralism within the WTO would allow us to keep up the hope that in the future multilateralism could get reinvigorated in ways that takes trade justice more seriously.

In any event, it makes more sense to maintain such hope under that scenario than if the WTO disintegrates entirely as a reflection of increasing economic nationalism. And any efforts of starting an entirely new organization that puts trade justice at the core of its mission would be rather quixotic in times when even multilateralism of the sort embodied by the WTO is so heavily under siege. For that reason it also seems that, for now, even a largely unreformed WTO is better than megaregionalism from a standpoint of global justice. But this could in any event be the outcome only 'for now' because the technological change that drives megaregionalism and plurilateralism in the first place is here to stay. 
There have been a number of failed attempts to create a postwar trade regime that would allow the newly independent former colonies to find their place in a world created by the imperial powers that had been holding sway for some centuries. ${ }^{40}$ The WTO is what has remained of all these efforts, and it came about when the guiding idea no longer was integration of developing countries for their own sake but protection and expansion of Northern economic activity. Unfortunately, and rather tragically, it would be in line with the postwar history that the WTO would fall apart or be reduced in importance because its wealthy members are unwilling to accept especially the development-oriented mandate that as a matter of justice a trade organization must have and the current organization explores in its Doha round, at least in some form. The prospects for trade justice are grim.

\section{Mathias Risse \\ Professor of Philosophy and Public Policy \\ John F. Kennedy School of Government \\ Harvard University \\ email:mathias_risse@harvard.edu}

\section{the global justicenetwork}

